\title{
Penerapan Sistem Ekonomi Islam Oleh Karyawan Pondok Pesantren Dar El Hikmah Dalam Memberikan Kontribusi Untuk Meningkatkan Amal Usaha Yayasan
}

\author{
Ficha Melina1, Muhammad Arif ${ }^{2}$, Winda Hasta ${ }^{3 *}$ \\ $1,2 \& 3 *$ Fakultas Agama Islam (FAI) Universitas Islam Riau (UIR) Pekanbaru \\ Jl. Kaharuddin Nasution No. 113 Perhentian Marpoyan Pekanbaru 28284 \\ e-mail : fichamelina@fis.uir.ac.id; muhammadarif@fis.uir.ac.id
}

\begin{abstract}
Abstrak: Penelitian ini ditulis berdasarkan asumsi bahwa kemajuan ekonomi Islam sangat dipengaruhi oleh tingkat kesadaran masyarakat muslim sebagai subjek utama dalam perputaran roda perekonomian Islam, baik menyangkut transaksi, produksi, konsumsi dan aktivitas-aktivitas perekonomian lainnya yang dapat mendatangkan nilai profit bagi masyarakat itu sendiri ke arah hidup yang lebih layak dan sejahtera. Permasalahan dalam penelitian ini adalah bagaimana kontribusi karyawan pondok pesantren Dar El Hikmah dalam meningkatkan Amal Usaha Yayasan , apa saja kendala yang dihadapi karyawan pondok pesantren Dar El Hikmah dalam memberikan kontribusi untuk meningkatkan amal usaha yayasan. Sedangkan tujuan dari penelitian ini adalah untuk menjelaskan kontribusi karyawan pondok pesantren Dar El Hikmah dalam meningkatkan amal usaha yayasan, untuk mengetahui kendala yang dihadapi oleh karyawan pondok pesantren Dar El Hikmah dalam memberikan kontribusi untuk meningkatkan amal usaha yayasan. Penelitian ini merupakan penelitian lapangan (field Research) yang dilaksanakan di Pondok Pesantren Dar El Hikmah, Jl. Manyar sakti Km.12, kecamatan Tampan Provinsi Riau. Populasi dalam penelitian ini adalah seluruh karyawan tetap yang berada di dalam lingkungan pondok pesantren Dar El Hikmah yang berjumlah 150 orang, dan sampel dalam penelitian ini sejumlah 30 orang dengan cara pengambilan menetapkan $20 \%$ dari subyeknya. Hasil penelitian dapat disimpulkan bahwa kontribusi oleh karyawan pondok pesantren Dar El Hikmah dalam meningkatkan amal usaha yayasan belum diterapkan dengan baik, hal ini disebabkan kurangnya kesadaran dan pengetahuan karyawan dalam sistem ekonomi Islam. Mereka lebih mengenal sistem konvensional yang beredar selama ini dan karena minimnya bantuan untuk karyawan dalam menjalankan sistem ekonomi Islam yang terdapat didalam Pondok Pesantren Dar El Hikmah tersebut. Saran penulis agar karyawan pondok pesantren Dar El Hikmah lebih memperdalam pengetahuan mereka tentang perbedaan sistem ekonomi Islam dengan ekonomi konvensional dalam melaksanakan penerapan sistem ekonomi Islam dalam memberikan kontribusi untuk meningkatkan amal usaha yayasan. Serta karyawan harus lebih mengutamakan pengembangan usaha yang telah dikelola ataupun yang telah disediakan oleh yayasan.
\end{abstract}

Kata Kunci : Sistem Ekonomi Islam, Kontribusi, Amal Usaha Yayasan 


\section{PENDAHULUAN}

Ilmu ekonomi islam itu mempelajari aktivitas atau prilaku manusia secara aktual dan empirical, baik dalam produksi, distribusi maupun konsumsi berlandaskan syari'ah Islam yang bersumber dari alQur'an dan Hadis dengan tujuan mencapai kebahagiaan dunia dan akhirat (Mawardi, 2007).

Harus diakui bahwa ketika pemikiran dan konsep tentang ekonomi syari'ah ini diperkenalkan, kemudian diimplementasikan dalam berbagai isntitusi tersebut, sebagian dari kaum muslimin banyak yang ragu dan tidak percaya, bahwa ajaran Islam berkaitan dengan dunia ekonomi, perbankan, pasar modal, asuransi, dan lain sebagainya. Kaum muslimin diperintahkan untuk mengaplikasikan ajaran tersebut dalam semua tatanan kehidupannya, termasuk di bidang ekonomi, hal ini dikemukakan dalam QS. al- Baqarah ayat 208 yang artinya "Wahai orang-orang yang beriman, masuklah kamu ke dalam Islam secara keseluruhan, dan janganlah kamu turut langkah-langkah setan. Sesungguhnya setan itu musuh yang nyata bagimu (Akhmad Mujahidin, 2014).

Para pakar ekonomi merumuskan tujuan kegiatan ekonomi secara terperinci. Tujuan ini meliputi tujuan yang bersifat pribadi (individu) dan sosial (masyarakat). Tujuan pribadi yang dibolehkan antara lain pemenuhan kebutuhan pribadi dan keluarga. Menabung untuk jaminan hari tua dan keigninan untuk meninggalkan warisan bagi keturunan amat dianjurkan, sebagai tujuan usaha produktif yang dibenarkan. Memenuhi kebutuhan dasar pada dasarnya menjadi kewajiban setiap orang (Mawardi, 2007).

Ekonomi Islam sesungguhnya satu realitas "baru" dunia ilmiah modern saat ini. Dalam kurun waktu 50 tahun terakhir, ia terus tumbuh menyempurnakan diri ditengah-tengah bergamnya sistem sosial dan ekonomi konvensional yang bernbasiskan pada sistem sekuler. Dikatan "baru" dalam tanda petik, karena sesungguhnya ilmu ekonomi Islam sudah pernah dipraktikkan secara sempurna di masa Rasulullah hingga masa keemasan Daulah Islamiyah beberapa abad lalu (Edwin, 2006)

Namun haruslah diyakini, Ekonomi Islam bukan lahir sebagai reaksi atas dominan kapitalisme maupun sosialisme ketika itu. Ekonomi Islam lahir sebagai bagian dari totalitas kesempurnaan Islam itu sendiri. Islam harus dipeluk secara kaffah oleh umatnya, maka konsekuensinya umat Islam harus mewujudkan keIslamannya dalam segala aspek kehidupan, termasuk kehidupan ekonomi. Karena sesungguhnya, umat Islam telah memiliki sistem ekonomi tersendiri di mana garis-garsi besarnya telah digambarkan secara utuh dalam Al-Qur'an dan As-Sunnah.

Qur'an surah Al-Jaatsiyah: 12

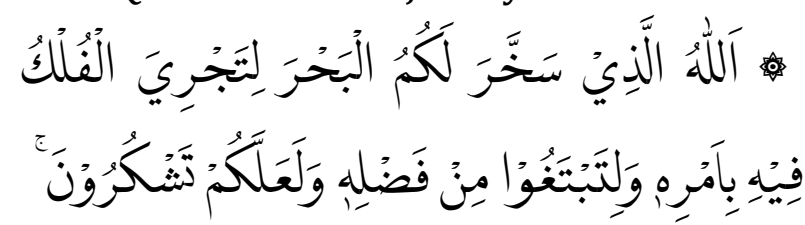

Artinya: "Allah-lah yang menundukkan lautan untukmu supaya kapalkapal dapat berlayar padanya dengan seizin-Nya dan supaya kamu dapat mencari karunia-Nya dan mudah-mudahan kamu bersyukur" (QS. al-Jaatsiyah: 12)

Tentu saja Allah SWT telah menetapkan aturan-aturan dalam menjalankan kehidupan ekonomi. Allah SWT telah menetapkan batas-batas tertentu terhadap orilaku manusia sehingga menguntungkan satu individu tanpa mengorbankan hak-hak individu lainnya. Prilaku mereka yang ditetapkan oleh 
hukum Allah (Syari'ah) harus diawasi oleh masyarakat secara keseluruhan, berdasarkan aturan Islam. Yang dimaksud dengan istilah ini adalah perangkat perintah dan aturan sosial, politik, agama, dan hukum yang mengikat masyarakat. Lembaga-lembaga sosial disusun sedemikian rupa untuk mengarahkan indvidu-individu, sehingga mereka secara baik melaksanakan aturan-aturan ini dan mengontrol serta mengawasi berjalannya aturan-aturan tersebut (Mustafa Edwin, 2006).

Perilaku manusia disini berkaitan dengan landasan-landasan syari'at sebagai rujukan berprilaku dan kecenderungankecenderungan dari fitnah manusia. Dalam ekonomi Islam, kedua hal tersebut berinteraksi dengan porsinya masingmasing hingga terbentuklah sebuah mekanisme ekonomi khas dengan dasardasar kurang nebdapat perhatian dan citra yang baik dimata masyarakat maka perkembangan lembaga keuangan syari'ah di Indonesia berjalan relatif lambat (Sholehuddin, 2007).

Seiring berjalannya waktu Pondok Pesantren Darel Hikmah ingin mewujudkan pembangunan SMK perbankan dengan konsentrasi keahlian ekonomi Islam yang diharapkan akan membantu para karyawan dan staf-staf pondok pesantren Dar El Hikmah dalam mengetahui konsep ekonomi syari'ah. Dalam bingkai ini penulis tertarik untuk meneliti ditempat ini, karena yang menjadi pertanyaan apakah para karyawan dan pegawai serta masyarakat yang hidup dilingkungan pesantren yang biasanya dikenal di masyrakat luas mereka secara keseluruhan mengerti perbedaan antara konsep syari'ah dan yang bukan syari'at. Menurut bapak Djeprin E Hulawa M.Ag (Kabid Kesantrian yang sudah 20 tahun lebih bekerja sebagai pegawai tetap di Yayasan Nur Iman), terdapat kontribusi untuk menigkatkan amal usaha yayasan seperti contoh: terdapat kebun sawit sebanyak 20 hektare yang akan dikembangkan menjadi 200 hektare terletak di Kab. Kampar dan Simpang Beringin. Kecuali itu, terdapat peternakan di Pangkalan Baru sejumlah 150 ekor sapi dan kerbau. Koperasi syari'ah guru dan para karyawan dimana koperasi ini berguna untuk membantu yayasan dalam meningkatkan amal usahanya. Disamping itu juga terdapat kantin pelajar sebagai sarana pembelajaran praktik ekonomi syari'ah bagi santri. Kantin ini juga berperan sebagai tempat penitipan barang dalam bentuk bagi hasil yang tidak saja menguntungkan bagi santri itu sendiri, tetapi bagi pihak Yayasan dalam meningkatkan sumber keuangan atau amal usaha yayasan.

\section{TINJUAN PUSTAKA}

\section{Pengertian Kontribusi}

Kontribusi menurut kamus bahasa Indonesia sumbangan atau pemberian, jadi kontribusi adalah pemberian adil setiap kegiatan, peranan, masukan ide, dan lain sebagainya. Menurut kamus ekononomi kontribusi adalah suatu yang diberikan bersama-sama dan pihak lain untuk tujuan biaya atau kerugian tertentu bersamasama(Guritno, 1992). Menurut Dany H. Kontribusi diartikan sebagai uang sumbangan atau sokongan.

Kontribusi berarti individu tersebut juga berusaha meningkatkan efisiensi dan efektifitas hidupnya hal ini dilakukan dengan menajamkan posisi perannya, sesuatu yang kemudian menjadi bidang spesialis, agar lebih tepat sesuai dengan kompetensi. Kontribusi dapat diberikan dalam berbagai bidang yaitu pemikiran, kepemimpinan, profesionalisme, finansial, dan lainnya. 


\section{Pengertian Dan Penerapan Sistem Ekonomi Islam}

Teori ekonomi Islam sebenarnya bukan ilmu baru atau suatu yang diturunkan secara mendasar dari teori ekonomi yang ada sekarang. Sejarah membuktikan para pemikir Islam merupakan penemu atau peletak dasar semua bidang ilmu. Berikut ulusan bagaimaan peranan ekonomi Islam dalam teori ekonomi modern (Adiwarman karim, 2001).

Menurut lukman hakim, Ekonomi Islam sering menjadi masalahatau beragam sebutannya. Ada yang menyebutnya sebagai ekonomi ilahiyah, ekonomi syariah, atau ekonomi Qur'ani. Ekonomi Islam juga merupakan bagian dari bentuk usaha duniawinyang bernilai ibadah, juga merupakan suatu amanah, yaitu merupakan amanah dari suatu kewajiban kepada Allah dan kewajiban kepada sesama manusia (Abdul Aziz, 2008).

Menurut Muh. Said, Ilmu ekonomi islam adalah pengetahuan bagaimana penggalian dan implementasi sumberdaya material untuk memenuhi kebutuhan manusia dimana penggalian itu harus dengan syari'at Islam. Ekonomi Islam dibangun diatas empat landasan yaitu, tauhid, keadilan dan keseimbangan, kebebasan dan pertanggungjawaban.

Setiap sistem ekonomi memiliki ciri khasnya masing-masing yang membentuk fondasinya, dari fondasi itulah ia dapat dibedakan dan dikenali kapitalisme modern, yang muncul karena adanya industrialisasi yang cepat serta difasilitasi oleh kemajuann yang dicapai oleh manusia dalam sains dan tekhnologi, didasarkan pada ide perekonomian pasar bebas, tanpa atau sedikit sekali campur tangan pemerintah dibidang ekonomi, bunga dan perbankan. Di sisi lain, Islam menganut keadilan dan kejujuran dilapamgan ekonomi. Menurut Islam, ,manusia adalah khalifah atau wakil tuhan dalam seluruh rencana Tuhan, dan telah diberi hak pemilikan terbatas atas alat-alat produksi. Islam mengakui adanya campur tangan negara dalam kegiatan ekonomi dan menjamin kesejahteraan warganya. Penghapusan bunga, pelembagaan sedekah dan zakat, konsep halal dan haram, distribusi kekayaan yang merata, dilarangnya penimbunan dan menekankan pentingnya sirkulasi kekayaan (M. Sharif, 2012).

Berdasarkan analisis ilmiah perlu kiranya ada terobosan strategis untuk menjawab dan merumuskan konsep, memebuat langkah gradual, untuk membuat jaringan yang mewadahi gerakan ekonomi Islam.

Sistem ekonomi Islam, sistem didefinisikan sebagai suatu organisasi berbagai unsur yang saling berhubungan satu sama lain. Unsur-unsur tersebut juga saling mempengaruhi, dan saling bekerja sama untuk mencapai tujuan tertentu. Dengan pemahaman semacam itu, maka kita bisa menyebutkan bahwa sistem ekonomi merupakan organisasi yang terdiri dari bagian-bagian yang saling bekerja sama untuk mencapai tujuan ekonomi (Ahmad S, 2016).

Secara sederhana kita bisa mengatakan, sistem ekonomi Islam adalah suatu sistem ekonomi yang didasarkan pada ajaran dan nilai-nilai islam. Sumber dari keseluruhan nilai tersebut sudah tentu Al-Quran, As-sunnah, ijma' dan qiyas. Nilainilai sistem ekonomi Islam merupakan bagian integral dari keseluruhan ajaran Islam yang komprehensif dan telah dinyatakan Allah SWT. Sebagai ajaran yang sempurna (QS. al-Maaidah ayat 3)

Karena didasarkan pada nilai-nilai ilahiah, sistem ekonomi Islam tentu saja akan berbeda dengan sistem ekonomi 
kapitalis yang didasarkan pada ajaran kapitalisme, dan juga berbeda denfan sistem ekonomi sosialis yang didasarkan pada ajaran sosialisme. Memang dalam beberapa hal, sistem ekonomi Islam merupakan kompromi antara kedua sistem tersebut, namun dalam bnayak hal sistem ekonomi Islam berbeda sama sekali dengan kedua sistem tersebut. Sistem ekonomi Islam memiliki sifat-sifat baik dari kapitalisme dan sisoalisme, namun terlepas dari sifat buruknya.

Dalam membahas perspektif ekonomi Islam, ada satu titik awal yang benar-benar harus kita perhatikan yaitu: ekonomi dalam Islam itu sesungguhnya bermuara kepada akidah Islam, yang bersumber dari syariatnya. Ini baru dari satu sisi. Sedangkan dari sisi lain ekonomi Islam bermuara pada Al-Quran al karim dan As-sunnah Nabawiyah yang berbahasa Arab.

Ilmu ekonomi Islam merupaan ilmu pengetahuan sosial yang mempelajari masalah-masalah ekonomi rakyat yang diilhami oleh nilai-nilai Islam. Sejauh mengenai masalah pokok kekurangan, hampir tidak terdapat perbedaan apa pun antara ilmu ekonomi Islam dan ilmu ekonomi modern. Andaipun ada perbedaan itu terletak pada sifat dan volumenya (Mannan; 1993). Itulah sebabnya mengapa perbedaan pokok antara kedua sistem ilmu ekonomi dapat dikemukakan dengan memerhatikan penanganan masalah pilihan.

Dalam ilmu ekonomi modern masalah pilihan ini sangat tergantung pada macam-macam tingkah masing-masing individu. Mereka mungkin atau mungkin juga tidak memperhitungkan persyratanpersyaratan masyarakat. Namun dalam ilmu ekonomi Islam, kita tidaklah berada dalam kedudukan untuk mendistribusikan sumber-sumber semau kita. Dalam hal ini ada pembatasan yang serius berdasarkan ketetapan kitab suci Al-Quran dan sunnah atas tenaga individu. Dalam Islam, kesejahteraan sosial dapat dimaksimalkan jika sumber daya ekonomi juga dialokasikan sedemikian rupa, sehingga dengan pengaturan kembali keadaannya, tidak serorangpun menjadi lebih baik dengan menjadikan orang lain lebih buruk didalam kerangka Al-quran atau sunnah Artinya Islam tidak mengenal zero sum games.

Wacana mengenai penerapan ekonomi islam dalam aktivitas ekonomi sehari-hari telah dimulai Di Indoensia pada dekade 1970-an, namun tonggak utama perkembangan ekonomi Islam adalah dengan berdirinya salah satu bank syaria'ah pada tahun 1992. Perkembangan ekonomi Islam adalah wujud dari upaya menerjemahkan Islam sebagai rahmatan lil'alamin, Islam memiliki nilai-nilai universal yang mampu masuk ke dalam setiap sendi kehidupan manusia tidak hanya aspek duniawi termasuk di dalamnya dalam aktivitas ekonomi masyarakat.

Ilmu ekonomi Islam, singkatnya, merupakan kajian tentang prilaku ekonomi orang Islam representatif dalam masyarakat muslim modern. Berdasarkan komposisinya, ia bersifat normatif, bukan bersifat positif sebagaimana ilim ekonomi neo-klasik. Usha Robbin untuk memisahkan etika dan ilmu ekonomi tidak diakui sejumulah ahli sebagai 'tindakan benar' bahkan dalam ilmu eknonomi modern Tetapi, usaha demikian itu dalam ekonomi Islam secara keseluruhan salah alamat karena ilum ekonomi Islam menuntut dimasukkannya secara eskplisit nilai-nilai etik ke dalam kalkulus ekonomi yakni, menerima agama (Islam) sebagai sumber nilai etik tersebut. Sebagaimana ilmu ekonomi neo-klasik, ilmu ekonomi Islam menghubungkan tujuan-tujuan dengan 
sarana yang terbatas dengan banyak manfaat alternatif. Ilmu ekonomi Islam tidak akan membuat kemajuan sama sekali jika para praktisinya tidak mempertanyakan validitas pernyataanpernyataan spesifik dari disiplin mereka (Syed Nawab Haider Naqvi, 2003). Para ahli telah banyak mendefiniskan tentang apa yang dimaksud dengan ekoonomi Islam. Argumen ini meskipun salih berbeda formulasi kalimatnya, tetapi mengandung pengertian dasar yang sama. Pada dasarnya suatu ilmu pengetahuan yang berupaya memandang, meninjau, meneliti yang pada akhirnya menyimpulkan dan menyelesaikan permasalahanpermasalahan ekonomi dengan cara-cara Islami merupakan bagian dari definis ekonomika Islam itu sendiri. Yang dimaksud dengan cara-cara Islami disini adalah metode-metode yang diadasarkan atas ajaran agama islam. Menurut pengertian seperti ini, maka istilah yang juga sering digunakan adalah ekonomika Islam. Jadi ekonomika Islam atau ilmu ekonomi islami akan menitikberatkan segala aspek ontologinya pada ajaran agama Islam. Penegasan yang diberikan oleh beberapa ahli, bahwa ruang lingkup dari ekonomika Islam adalah masyarakat Muslim atau komunitas negara Muslim itu sendiri. Artinya, ia mempelajari prilaku ekonomi dari masyarakat atau negara Muslim dimana nilai-nilai ajaran islam diaplikasikan. Untuk memberikan pengertian yang lebih jelas maka berikut ini disampaikan definisi ekonomi Islam sebagai berikut (Sholahuddin, 2007; 6):

1. Ekonomi Islam adalah ilmu yang mempelajari masalah-masalah ekonomi masyarakat dalam perspektif nilai-nilai Islam.

2. Ekonomi Islam didefinisikan sebagai cabang ilmu yang membantu merealisasikan kesejahteraan manusia melalui alokasi dan distribusi sumber daya yang langka, yang sejalan dengan ajaran Islam, tanpa membatasi kebebasan individu ataupun menciptakan ketidakseimbangan makro dan ekologis.

3. Ekonomi Islam adalah tanggapan pemikir-pemikir Muslim terhadap tantangan ekonomi pada zamannya. Dalam upaya ini mereka dibantu oleh alQur'an dan Hadis, serta alasan dan pengalaman.

4. Ekonomi islam adalah suatu ilmu aplikasi petunjuk dan aturan syari'ah yang mencegah ketidakadilan dalam memperoleh dan menggunakan sumber daya meterial agar memenuhi kebutuhan manusia dan agar dapat menjalankan kewajibannya kepada Allah dan masyarakat.

5. Ekonomi Islam memusatkan perhatian pada studi tentang kesejahteraan manusia yang dicapai dengan mengorganisasikan sumber daya Di bumi atas dasar kerja sama dan partisipasi (Zulfa, 2019).

Amal Usaha Yayasan yang meningkatkan Perekonomian Islam

Pengertian usaha adalah bentuk usaha yang melakukan kegiatan secara tetap dan terus-menerus agar mendapatkan keuntungan, baik yang dilakukan oleh individu maupun kelompok yang berbentuk badan hukum atau tidak berbentuk badan hukum, didirikan dan berkedudukan di suatu tempat.

Usaha merupakan suatu kegiatan yang dilakukan dengan tujuan memperoleh hasil berupa keuntungan, upah, atau laba usaha.

Makna amal dalam Islam melampaui zakat dan shadaqah. Memberikan kekayaan publik bagi kemaslahatan umat (waqaf), membangun sebuah lingkungan di daerah kantong (hima) bagi keseimbangan ekologi, 
dan brang secara umum dan pertukaran di masyarakat secara individu dan kolektif, adalah bentuk amal (Akhmad Mujahidin, 2014).

Amal usaha Yayasan dapat dikelompokkan ke dalam beberapa kegiatan perekonomian, diantaranya;

a. Dalam bidang perkebunan contohnya: , karet yang luas nya mencapai 20 Hektar dan kebun sawit terdapat di simpang Bringin yang luasnya 14 Hektar.

b. Dalam bidang peternakan seperti: ayam, ikan (patin dan lele), sapi yang jumlahnya 150 ekor bertempat Di pangkalan Baru dan kerbau yang jumlahnya 50 ekor bertempat Di Kampar.

c. Koperasi mengelola kantin dan koperasi Induk terdapat dilokasi pekarangan santri Putra dan warung santri atau rumah makan putra putri yang dikelola oleh santrinya.

d. Wartel yang terdapat di lokasi Putra dan Putri dengan pemasukan omset kuarng lebih 500 ribu perharinya.

\section{METODE}

Penelitian ini merupakan penelitian lapangan yang mengambil lokasi di Pondok Pesantren Dar El Hikmah Pekanbaru, dengan alasan bahwa lembaga ini telah berdiri sejak tahun 1991 dan menerapkan pola hidup berasrama dimana seluruh civitas Pondok, baik guru, siswa dan karyawannya hidup dan tinggal bersama di dalam satu tempat yang memungkinkan perputaran roda perekonomian, terutama berlangsungnya aktivitas ekonomi syariah yang tentu saja sangat berimbas pada

Tabel 1 : Kontribusi yang Diberikan Oleh Karyawan di Pondok Pesantren Dar El Hikmah dalam meningkatkan amal usaha yayasan

\begin{tabular}{|c|l|c|c|}
\hline No Item & Alternatif jawaban & Frekuensi (f) & Persentase (p) \\
\hline & a.sumbangan sosial & 12 & $40 \%$ \\
\hline
\end{tabular}

peningkatan amal usaha yayasan. Adapun populasi penelitian ini berjumlah 150 orang, dengan mengambil sampel berjumlah 30 orang. Teknik yang digunakan dengan mempertimbangkan jumlah populasi dan sampel dalam penelitian ini yang berjumlah 150 orang karyawan, maka menurut Suharisimi Arikunto, apabila subyeknya kurang dari 100 orang lebih baik diambil semua sehingga penelitiannya merupakan penelitian populasi. Tetapi jika jumlah subyeknya lebih besar dapat diambil antara 10-15 \% atau 20-25\% atau lebih. Berdasarkan asumsi di atas, maka penulis menetapkan pengambilan subyeknya sebesar 20\% dari subyeknya.

Adapun data yang dikumpulkan dalam penelitian ini sesuai dengan sifat penelitian yaitu lapangan dan perpustakaan, maka dengan landasan tersebut pengumpulan datanya dengan cara, observasi, angket, dokumentasi, dan wawancara.

Analisa yang penulis gunakan dalam penelitian ini adalah Analisa Kualitatif yaitu analisa dengan jalan mengklasifikasikan data-data berdasarkan persamaan jenis dari data-data tersebut, diuraikan sedemikian rupa sehingga diperoleh gambaran yang utuh dari permasalahan yang diteliti.

\section{PEMBAHASAN}

Penerapan Sistem Ekonomi Islam oleh karyawan Pondok Pesantren Dar El Hikmah dalam Memberikan Kontribusi untuk Meningkatkan Amal Usaha Yayasan 


\begin{tabular}{|c|l|c|c|}
\hline \multirow{2}{*}{1.} & b.sumbangan modal & 8 & $26,67 \%$ \\
\cline { 2 - 4 } & $\begin{array}{l}\text { c.pembuatan dan } \\
\text { penjagaan koperasi }\end{array}$ & 7 & $23,33 \%$ \\
\cline { 2 - 4 } & d.tidak ada kontribusi & 3 & $10 \%$ \\
\hline \multicolumn{2}{|c|}{ Jumlah } & 30 & $100 \%$ \\
\hline
\end{tabular}

Sumber: Data Olahan Penelitian, 2017

Dari tabel diatas dapat diketahui bahwa responden yang memberikan kontribusi berupa sumbangan sosial sebanyak 12 orang (40\%), responden yang memberikan kontribusi berupa sumbangan modal sebanyak 8 orang $(26,67 \%)$, responden yang memberikan kontribusi berupa pembuatan dan penjagaan koperasi sebanyak 7 orang $(23,33 \%)$, dan responden yang tidak memberikan kontribusi sebanyak 3 orang (10\%).
Dan dari sekian karyawan yang memberikan sumbangan berupa modal hanya sebagian kecilnya saja dari tabel ini tentu telah bisa disimpulkan bahawa minimnya dorongan untuk para karyawan agar lebih berkontribusi demu meningkatkan amal usaha yayasan.

Untuk mengetahui kendala yang diahadapi dalam memberikan kontribusi dalam penerapan sistem ekonomi Islam maka telah penulis sajikan dalam bentuk tabel dibawah ini:

Tabel 2 : Kendala yang Dihadapi karyawan dalam Memberikan Kontribusi untuk Meningkatkan Amal Usaha Yayasan

\begin{tabular}{|l|l|c|c|}
\hline No Item & Alternatif Jawaban & Frekuensi (f) & Persentase (p) \\
\hline \multirow{2}{*}{1.} & a.Ada & 18 & $60 \%$ \\
\cline { 2 - 4 } & b.Tidak Ada & 12 & $40 \%$ \\
\hline \multicolumn{2}{|c|}{ Jumlah } & $\mathbf{3 0}$ & $\mathbf{1 0 0 \%}$ \\
\hline
\end{tabular}

Sumber: Data Olahan Penelitian, 2017

Dari tabel diatas dapat diketahui bahwa kendala yang dihadapi oleh responden yaitu sejumlah 18 orang (60\%), dan responden yang menjawab tidak adanya masalah yaitu sejumlah 12 orang (40\%).

Dari tabel 2 diatas bisa dilihat bahwan lebih banyak karyawan yang mendapatkan kendala sehingga mereka enggan untuk berkontribusi. 
Tabel 3 : Motivasi dalam Memberikan Kontribusi Oleh Karyawan Pondok Pesantren Dar el Hikmah

\begin{tabular}{|c|l|c|c|}
\hline No Item & \multicolumn{1}{|c|}{ Alternatif jawaban } & Frekuensi (F) & Persentase (p) \\
\hline \multirow{3}{*}{} & $\begin{array}{l}\text { a.Untuk meingkatkan mutu } \\
\text { dan kualitas yayasan }\end{array}$ & 7 & $23,33 \%$ \\
\cline { 2 - 4 } & $\begin{array}{l}\text { b.untuk meningkatkan } \\
\text { kualitas keuangan yayasan }\end{array}$ & 3 & $10 \%$ \\
\cline { 2 - 4 } & $\begin{array}{l}\text { c.Untuk memudahkan } \\
\text { pengelolaan koperasi }\end{array}$ & 12 & $40 \%$ \\
\cline { 2 - 4 } 3. & $\begin{array}{l}\text { d.Untuk membantu yayasan } \\
\text { dalam memperoleh nama } \\
\text { baik yayasan itu sendiri }\end{array}$ & 8 & $\mathbf{1 0 0} \%$ \\
\hline \multicolumn{2}{|l}{ Jumlah } & $\mathbf{3 0}$ & $26,67 \%$ \\
\hline
\end{tabular}

Sumber: Data Olahan Penelitian, 2017

Dari tabel diatas dapat diketahui bahwa responden yang memberikan motivasi guna untuk meningkatkan mutu dan kualitas yayasan sejumlah 7 orang $(23,33 \%)$, responden yang memberikan motivasi guna untuk meningkatkan kualitas keuangan yayasan sejumlah 3 orang (10\%), responden yang memberikan motivasi untuk memudah kan pengelolan koperasi sejumlah 12 orang (40\%), dan responden yang memberikan motivasi guna untuk membantu yayasan memperoleh nama baik yayasan itu sendiri sejumlah 8 orang $(26,67 \%)$.

Dari tabel 3 diatas telah mampu terjawab bahwasanya karyawan lebih memilih untuk pengelolalan koperasi dalam berkontribusi dibandingkan dalam meningkatkan amal usaha yayasan.

Kemudian untuk mengetahui berapa waktu yang digunakan responden dalam memberikan kontribusi terhadap sistem ekonomi Islam dapat dilihat pada tabel dibawah ini:

Tabel 4 : Waktu dalam Memberikan Kontribusi Oleh Karyawan Pondok Pesantren Dar El Hikmah

\begin{tabular}{|c|l|c|c|}
\hline \multirow{2}{*}{ No Item } & \multicolumn{1}{|c|}{ Alternative jawaban } & Frekuensi (f) & Persentase (p) \\
\hline \multirow{3}{*}{6.} & a.Modal sendiri & 3 & $10 \%$ \\
\cline { 2 - 4 } & b.Modal pinjaman & 17 & $56,67 \%$ \\
\cline { 2 - 4 } & c.Modal usaha/koperasi & 5 & $16,67 \%$ \\
\cline { 2 - 4 } & d.Modal oragnisasi & 5 & $16,67 \%$ \\
\hline & Jawaban & $\mathbf{3 0}$ & $\mathbf{1 0 0} \%$ \\
\hline
\end{tabular}

Sumber: Data Olahan Penelitian, 2017 
Dari tabel diatas dapat diketahui bahwa responden yang memberikan kontribusi yang paling lama adalah selama 1 tahun dengan jumlah responden sebanyak 15 orang (50\%), kemudian responden yang memberikan kontribusi selama 1 bulan sejumlah 4 orang $(26,67 \%)$, responden yang memberikan kontribusinya selama lebih dari satu tahun sebanyak 8 orang $(13,33 \%)$ dan responden yang paling sedikit memberikan kontribusinya dalam penerapan ekonomi Islam ialah sejumlah 3 orang (10\%).
Dan dari tabel 4 diatas telah dapat diketahui minimnya untuk meningkatkan amal usaha yayasan karena pihak yayasan memberi waktu yang kooperatif lama dalam berkontribusi padahal pimpinan yayasan itu sendiri juga telah membuka peluang bagi karyawan dalam berkontribusi seperti menjalankan kotak amal disetiap pertemuan/rapat.

Untuk mengetahui keadaan yayasan setelah mendapat kontribusi dari karyawan dalam penerapan sistem ekonomi Islam dapat dilihat pada tabel; dibawah ini:

Tabel 5 : Keadaan Yayasan Setelah Mendapatkan Kontribusi Dari Karyawan dalam Meningkatkan Amal Usaha Yayasan

\begin{tabular}{|c|l|c|c|}
\hline \multirow{2}{*}{ No Item } & Alternative Jawaban & Frekuensi (f) & $\begin{array}{c}\text { Persentase } \\
\text { (p) }\end{array}$ \\
\hline \multirow{3}{*}{5.} & a.Meningkat & 13 & $43,33 \%$ \\
\cline { 2 - 4 } & b.Sangat meningkat & 9 & $30 \%$ \\
\cline { 2 - 4 } & c.Kurang meningkat & 5 & $16,67 \%$ \\
\cline { 2 - 4 } & d.Tidak meningkat & 3 & $10 \%$ \\
\hline \multicolumn{2}{|c|}{ Jumlah } & $\mathbf{3 0}$ & $\mathbf{1 0 0} \%$ \\
\hline
\end{tabular}

Sumber: Data Olahan Penelitian, 2017

Dari tabel diatas dapat diketahui bahwa responden yang menilai keadaan yayasan setelah mendapatkan kontribusi dalam penerapan ekonomi Islam ialah yang sangat meningkat sejumlah 9 orang (30\%), dan yang responden yang berpendapat bahwa keadaan yayasan setelah mendapatkan kontribusi yang meningkat ialah 13 orang $(43,33 \%)$, kemudian responden yang menilai kurang adanya peningkatan setelah mendapatkan kontribusi sejumlah 5 orang $(16,67 \%)$, dan responden yang menilai tidak adanya peningkatan setelah mendapatkan kontribusi ialah sejumlah 3 0orang (10\%).

Selanjutnya untuk mengetahui dari mana modal yang diberikan oleh responden dalam penerapan ekonomi Islam dan guna untuk meningkatkan amal usaha yayasan,juga telah penulis sajikan dalam tabel dibawah ini: 
Tabel 6 : Modal Yang Diperoleh Untuk Berkontribusi dalam Meningkatkan Amal Usaha Yayasan

\begin{tabular}{|c|l|c|c|}
\hline $\begin{array}{c}\text { No } \\
\text { Item }\end{array}$ & Alternative jawaban & Frekuensi (f) & $\begin{array}{c}\text { Persentase } \\
\text { (p) }\end{array}$ \\
\hline \multirow{3}{*}{6.} & a.Modal sendiri & 3 & $10 \%$ \\
\cline { 2 - 4 } & b.Modal pinjaman & 17 & $56,67 \%$ \\
\cline { 2 - 4 } & $\begin{array}{l}\text { c.Modal } \\
\text { usaha/koperasi }\end{array}$ & 5 & $16,67 \%$ \\
\cline { 2 - 4 } & d.Modal oragnisasi & 5 & $16,67 \%$ \\
\hline \multicolumn{2}{|c|}{ Jawaban } & $\mathbf{3 0}$ & $\mathbf{1 0 0 \%}$ \\
\hline
\end{tabular}

Sumber: Data Olahan Penelitian, 2017

Dari tabel diatas dapat diketahui membantu meningkatkan amal usaha bahwa responden yang memberikan kontribusi dalam penerapan sistem Ekonomi Islam untuk meningkatkan amal usaha yayasan yang merupakan dari modal sendiri sejumlah 17 orang $(56,67 \%)$, yang memberikan kontribusi dengan modal pinjaman sejumlah 3 orang $(10 \%)$, kemudian yang memberikan kontribusi dengan modal usaha/koperasi sejumlah 5 orang $(16,67 \%)$, dan yang memberikan kontribusi dengan modal organisasi yaitu sejumlah 5 orang $(16,67 \%)$.

Dari tabel 6 terdapat kendala yang dihadapi dalam berkontribusi karena karyawan yang berkontribusi dalam yayasan lebih banyak meminjam modal dibandingkan modal sendiri dan dari modal pinjaman tersebut para karyawan terbebani untuk berkontribusi karena mereka berfikir setelah berkontribusi mereka harus membayar pinjaman tersebut.

Untuk mengetahui apakah kontribusi yang diberikan oleh karyawan pondok pesantren Dar El Hikmah berpengaruh atau tidaknya terhadap kemajuan amal usaha yayasan, dapat dilihat pada tabel yang penulis sajikan dibawah ini:

Tabel 7 : Kontribusi Berpengaruh terhadap Kemajuan Amal Usaha Yayasan

\begin{tabular}{|c|l|c|c|}
\hline No Item & \multicolumn{1}{|c|}{$\begin{array}{c}\text { Alternative } \\
\text { jawaban }\end{array}$} & Frekuensi (f) & $\begin{array}{c}\text { Persentase } \\
\text { (p) }\end{array}$ \\
\hline \multirow{3}{*}{7.} & a.Ada & 20 & $66,67 \%$ \\
\cline { 2 - 4 } & b.Ragu-ragu & 3 & $10 \%$ \\
\cline { 2 - 4 } & c.Tidak ada & 2 & $6,67 \%$ \\
\cline { 2 - 5 } & d.Tidak tahu & 5 & $\mathbf{1 6 , 6 7 \%}$ \\
\hline \multicolumn{2}{|c|}{ Jawaban } & $\mathbf{3 0}$ & $\mathbf{1 0 0 \%}$ \\
\hline
\end{tabular}

Sumber:Data Olahan Penelitian, 2017 
Dari tabel diatas dapat diketahui bahwa responden yang merasa adanya pengaruh atau tidaknya setelah mendapatkan amal usaha yayasan sejumlah 20 orang $(66,67 \%)$, responden yang merasa ragu-ragu terhadap berepngaruhnya setelah mendapat kontribusi sejumlah 3 orang $(10 \%)$, kemudian responden yang nerasa tidak adanya pengaruh dalam mendapatkan kontribusi sejumlah 2 orang
(6,67\%), dan responden yang tidak tahu berpengaruh tidaknya setelah mendapatkan kontribusi ialah sejumlah 5 orang $(16,67 \%)$.

Untuk mengetahui apakah karyawan yang berada didalam pondok pesantren Dar El hikmah merasa dirugikan dalam memberikan kontribusinya, dan dapat dilihat pada tabel yang penulis sajikan dibawah ini:

Tabel 8 : Responden Merasa Dirugikan dalam Memberikan Kontribusi Untuk Meningkatkan Amal Usaha Yayasan

\begin{tabular}{|c|l|c|c|}
\hline $\begin{array}{c}\text { No } \\
\text { Item }\end{array}$ & \multicolumn{1}{|c|}{$\begin{array}{c}\text { Alternative } \\
\text { jawaban }\end{array}$} & Frekuensi (f) & $\begin{array}{c}\text { Persentase } \\
\text { (p) }\end{array}$ \\
\hline \multirow{2}{*}{8.} & a. Ya & 19 & $63,33 \%$ \\
\cline { 2 - 4 } & b.Tidak & 11 & $36,67 \%$ \\
\hline \multicolumn{2}{|c|}{ Jumlah } & $\mathbf{3 0}$ & $\mathbf{1 0 0 \%}$ \\
\hline
\end{tabular}

Sumber: Data Olahan Penelitian, 2017

Dari tabel diatas dapat diketahui ekonomi Islam ialah sejumlah 25 orang bahwa responden yang merasa dirugikan dalam memberikan kontribusi terhadap penerapan sitem ekonomi Islam ialah sejumlah 5 orang $(16,67 \%)$, sedangkan yang tidak merasa dirugikan dalam berkontribusi terhadap penerapan sistem $(83,33 \%)$.

Selanjutnya untuk mengetahui bagaimana cara karyawan memberikan kontribusi dalam penerapan ekonomi Islam dapat dilihat pada tabel yang penulis sajikan dibawah ini:

Tabel 9 : Cara Memberikan Kontribusi dalam meningkatkan Amal Usaha Yayasan

\begin{tabular}{|c|c|c|c|}
\hline $\begin{array}{c}\text { No } \\
\text { Item }\end{array}$ & Alterntive Jawaban & Frekuensi (f) & $\begin{array}{c}\text { Persentase } \\
\text { (p) }\end{array}$ \\
\hline \multirow{2}{*}{9.} & a.Sumbangan materi & 8 & $26,67 \%$ \\
\cline { 2 - 4 } & b.Sumbangan fikiran & 15 & $50 \%$ \\
\cline { 2 - 4 } & c.Sumbangan tenaga & 7 & $23,33 \%$ \\
\hline & Jumlah & $\mathbf{3 0}$ & $\mathbf{1 0 0 \%}$ \\
\hline
\end{tabular}

Sumber: Data Olahan penelitian, 2017 
Dari tabel diatas dapat dilihat bahwa responden paling banyak memberikan kontribusi berupa sumbangan berupa fikiran yaitu sejumlah 15 orang (50\%), kemudian responden yang memberikan kontribusi berupa sumbangan berupa materi sejumlah 8 orang $(26,67 \%)$, dan responden yang memberikan kontribusi berupa sumbangan tenaga ialah sejumlah orang $(23,33 \%)$.

Dan dari tabel diatas bisa dilihat bahwasanya para karyawan lebih banyak berkontribusi berupa fikiran dibandingkan materi sedangkan dalam meningkatkan amal usaha yayasan seharusnya para karyawan lebih memilih berkontribusi berupa materi dibandingkan yang lainnya.

Dan dan kemudian untuk mengetahui apakah seluruh kjaryawan tetap yang berada didalam pondok pesantren Dar El Hikmah ikut serta memberikan kontribusi dalam penerapan sistem ekonomi Islam dapat dilihat pada tabel yang penulis sajikan dibawah ini:

Tabel 10 : Semua Karyawan Pondok Pesantren Dar El Hikmah Ikut Memberikan Kontribusi Dalam Meningkatkan Amal Usaha Yayasan

\begin{tabular}{|c|l|c|c|}
\hline $\begin{array}{c}\text { No } \\
\text { Item }\end{array}$ & Alternative jawaban & Frekuensi (f) & $\begin{array}{c}\text { Persentase } \\
\text { (p) }\end{array}$ \\
\hline \multirow{2}{*}{10.} & a. Ya & 10 & $33.33 \%$ \\
\cline { 2 - 4 } & b.Tidak & 20 & $66,67 \%$ \\
\hline \multicolumn{2}{|c|}{ Jumlah } & $\mathbf{3 0}$ & $\mathbf{1 0 0 \%}$ \\
\hline
\end{tabular}

Sumber: Data Olahan Penelitian, 2017

Dari tabel diatas dapat diketahui bahwa responden yang ikut dalam memberikan kontribusi dalam penerapan sistem ekonomi Islam untuk meningkatkan amal usaha yayasan sejumlah 20 orang $(66,67 \%)$, dan responden yang tidak memberikan kontribusi dalam penerapan sistem ekonomi Islam dalam meningkatkan amal usaha yayasan sejunlah 10 orang (33,33\%).

Dan dari tabel 10 ini jelas bahwa kurangnya kontribusi dan kesadaran para karyawan dalam membantu meningkatkan amal usaha yayasan karena tidak semua karyawan ikut serta dalam berkontribusi disebabkan adanya kendala yang mereka hadapi contohnya saja keterlambatan mereka dalam menerima gaji kurangnya sosial mereka antar sesama karyawan hal ini menyebabkan mereka kurang mengetahui keadaan lingkungan sekitarnya.

Kendala yang Dihadapi Oleh Karyawan Pondok Pesantren Dar El Hikmah dalam Memberikan Kontribusi untuk Meningkatkan Amal Usaha Yayasan.

Didalam menerapkan sistem ekonomi syari'ah di pondok pesantren Dar El Hikmah terdapat beberapa kendala di dalamnya yang pertama bahwa kurang sadarnya para karyawan dengan sistem syaria'ah yang telah berkembang di dunia sekarang ini mereka lebih banyak bersosialisasi dengan sistem konvensional sehingga sedikit banyaknya lupa dengan 
aturan Islam yang telah ada sejak zaman Rasulullah.

Al-Qur'an mendesak orang-orang yang beriman, yang memiliki kemampuan fisik untuk bekerja keras, dan Allah menjanjikan pertolongan bagi siapa-siapa saja yang berjuang dan berlaku baik. Qs: Al- Ankabut: 69

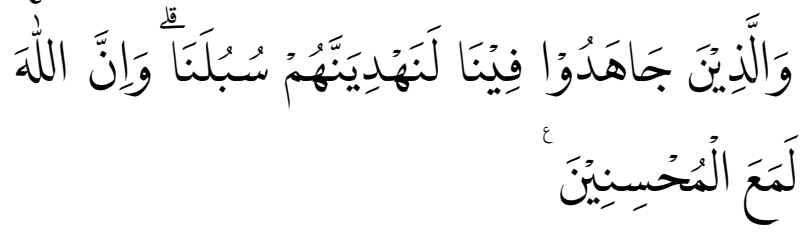

Artinya: Dan orang-orang yang berjihad untuk (mencari keridhaan) kami, benar- benar akan kami tunjukkan kepada mereka jalanjalan kami. dan Sesungguhnya Allah benar-benar beserta orangorang yang berbuat baik. seperti transportasi yang digunakan dalam acara-acara wirid dan pengajian bulanan yang secara bergiliran di adakan di rumah-rumah/kediaman guru dan karyawanran pondok. Padahal dalam kaidah Ushul Fiqh dikatakan " al"Amru bi wujubihi 'amrun bi wasaailihi" (Perintah untuk melaksanakan kewajiban selalu diiringi oleh pemenuhan fasilitasnya).

2. Kurangnya sosialisasi dan pembelajaran khusus terkait praktik ekonomi syari'ah dari pihak berkompeten, dalam hal ini ahli ekonomi Islam.

\section{SIMPULAN}

Berdasarkan hasil penelitian dan analisa yang penulis lakukan, maka dapat diambil kesimpulan sebagai berikut:

1. Penerapan sistem ekonomi Islam di Pondok Pesantren Dar El Hikmah belum berjalan dengan baik terlihat dari kurangnya kesadaran karyawan dalam aktifitas ekonomi yang berdasarkan syari'at Islam, di samping kurangnya motivasi dari pihak Yayasan dalam memberikan pengetahuan yang lebih komprehensif tentang sistem ekonomi Islam itu sendiri.

Artinya: Padahal sesunggunya sebagai penganut muslim diharuskan melaksanakan praktik keagamaan Islam secara totalitas, bukan saja pada praktik pengamalan keagamaan, tetapi juga pada praktik pelaksanaan ekonomi, transaski, muamalat, dan benttuk kegiatan lainya, sebagaimana yang disinyalir oleh Allah SWT. Dalam Q.S alBaqarah: 27

Yang dihadapi para karyawan dalam memberikan kontribusi untuk meningkatkan amal usaha yayasan yaitu:

1. Minimnya sarana pendukung kearah terciptanya kegiatan ekonomi syari'ah,
2. Kurangnya perhatian karyawan dalam memajukan amal usaha Yayasan yang tentu saja berimbas kepada minimnya hasil/keuntungan ekonomi yang diperoleh pihak Yayasan

3. Minimnya alat transportasi guna mendukung seluruh kegiatan yang bersifat sosial maupun aktivitas yang berhubungan dengan peningkatan ekonomi syari'ah lainnya yang dapat meningkatkan amal usaha yayasan tersebut.

4. Minimnya pengetahuan tentang penerapan sistem ekonomi Islam yang baik dan benar, baik oleh 
karyawan maupun pihak Yayasan itu sendiri

5. Kurangnya kesadaran untuk mengembangkan diri dan menggali potensi hidup yang lebih baik dan sejahtera melalui aktivitas ekonomi Islam yang tersaji di berbagai sektor kehidupan

6. Kurangnya pendidikan dan pelatihan khusus tentang penerapan sestem perekonomian syari'ah yang diberikan oleh para ahli di bidangnya.

\section{DAFTAR RUJUKAN}

Aziz, Abdul. 2008. Ekonomi Islam Analisis Mikro dan Makro. Candi Gerbang Permai, Cet. Ke-1, Yogyakarta.

Ahmad, S. Pendidikan Kemandirian dalam Islam. Journal Sport Area, 1(2), 5967.

Al Arif, M.Nur Rianto. 2010. Teori Mikro Ekonomi (Suatu Perbandingan Ekonomi Islam Dan Ekonomi Konvensional). Kencana, cet. Ke-1, Jakarta.

Arikunto, Suharsimi. 2006. Prosedur Penelitian Suatu Pendekatan Praktik. PT Rineka Cipta, cet ke-13, Jakarta.

Chaudhry, Muhammad Sharif. 2012. Sistem Ekonomi Islam: Prinsip Dasar. Kencana, Cet-1, Jakarta.

Dany, H. 2006. Kamus Ilmiah Populer. Gita Media press, Surabaya.

Guritno, T. 1992. Kamus Besar Bahasa Indonesia dan Kamus Ekonomi. Cet. Ke-11, Jakarta.

Hakim, Lukman, Prinsip-Prinsip Ekonomi Islam, Erlangga: PT. Gelora Aksara Pratama, Cet. Ke-3.

Karim, Adhiwarman A. 2001. Ekonomi Islam Suatu Kajian Kontemporer. Gema Insani Press, Cet. Ke-1, Jakarta.
Mujahidin, Akhmad. 2014. Ekonomi Islam 2. Al-Mujtahadah Press, cet ke-1, Pekanbaru.

Mawardi. 2007. Ekonomi Islam. Alaf Riau, Pekanbaru.

Melina, F. (2018). Pembiayaan Pinjaman Lunak Usaha Kecil Ikan Patin dengan PT. Telkom Pekanbaru Melalui Mitra Binaan Menurut Ekonomi Islam. Syarikat: Jurnal Rumpun Ekonomi Syariah, 1(1), 53-62.

Nasution, dkk. 2006. Pengenalan Ekslusif Ekonomi Islam. Kencana, cet ke-2, Jakarta.

Naqvi, Syed Nawab Haider. 2003. Menggagas Ilmu Ekonomi Islam, Pustaka Bleajar, Cet ke-1, Yogyakarta.

Pusat Pengkajian dan Pengembangan Ekonomi Islam (P3EI). 2008. Ekonomi Islam. PT.Raja Grafindo Persada, Cet.ke-1, Jakarta.

Said HM, Muh. 2008. Pengantar Ekonomi Islam Dasar-dasar dan Pengembangan. Suska Press, Cet. Ke1, Pekanbaru.

Sholahuddin, M. 2007. Asas-Asas Ekonomi Islam. PT. Raja Grafindo Persada, Cet. Ke-1, Jakarta.

Zulfa, M. (2019). Analisis Persepsi Masyarakat Industri Kecil Terhadap Pelaksanaan Pembiayaan Bagi Hasil Bank Riau Kepri Cabang Syariah Pekanbaru. Jurnal Tabarru': Islamic Banking and Finance, 2(1), 1-11.

http://dilihatya.com/1741/pengertianusaha-menurut-para-ahli

http://matakristal.com/pengertian-usahaperusahaan-dan-badan-usaha/ 